\title{
Phloroglucinol is Effective for in vitro Growth and Multiplication of Musa accuminata Cv. Grand Naine Shoots and Roots
}

\author{
Luciana Cardoso Nogueira Londe ${ }^{1^{\star}}$, Wagner A. Vendrame ${ }^{2}$, \\ Alexandre Bosco De Oliveira ${ }^{3}$, Massy Sanaey ${ }^{2}$ and Annanda Mendes Costa ${ }^{4}$ \\ ${ }^{1}$ Empresa de Pesquisa Agropecuaria de Minas Gerais, Rodovia MGT 122, $m$ 155. Campo \\ Experimental do Gorutuba, Nova Porteirinha, MG, 39.525-000, Brazil. \\ ${ }^{2}$ Tropical Research and Education Center, University of Florida, 18905 SW $280^{\text {th }}$ St. Homestead, \\ FL, 33031, USA. \\ ${ }^{3}$ Center of Agricultural Sciences, Department of Crop Science, Universidade Federal do Ceará, \\ Av. Mister Hull, 2977. Fortaleza, CE. 60356-001, Brazil. \\ ${ }^{4}$ Instituto Federal de Mato Grosso do Sul, Rodovia, BR-463, km 14, s/nº, Ponta Porã, MS, \\ 79909-000, Brazil.
}

\section{Authors' contributions}

This work was carried out in collaboration between all authors. Author LCNL designed the study, performed the statistical analysis, wrote the protocol, managed the analyses of the study and wrote the first draft of the manuscript. Authors WAV and ABDO performed the statistical analysis and managed the analyses of the study. All authors read and approved the final manuscript.

Article Information

DOI: $10.9734 / \mathrm{JABB} / 2017 / 33718$

Editor(s):

(1) Maria Serrano, Department of Applied Biology, EPSO, University Miguel Hernandez, Orihuela, Alicante, Spain.

Reviewers:

(1) Dariusz Kulus, UTP University of Science and Technology, Poland. (2) P. Velayutham, Government Arts College (Autonomous), India. Complete Peer review History: http://www.sciencedomain.org/review-history/19354

\begin{abstract}
Despite being a major staple food in the world, banana production in the United States is still limited, with about 500 acres under cultivation. Micropropagation has been an effective method for the large-scale production of bananas to meet both domestic and international markets. However, the efficiency of micropropagation protocols depends on several factors, particularly on the types, combinations, and levels of plant growth regulators used in the culture media. Phloroglucinol is a growth regulator that acts synergistically with auxins and cytokinins. The use of phloroglucinol for
\end{abstract}


the production and development of in vitro plantlets of Musa spp. cv. Grande Naine were investigated. Multiplication and elongation of shoots and roots in vitro was enhanced by the addition of $200 \mu \mathrm{M}$ phloroglucinol to MS medium, as compared to the control with $13.2 \mu \mathrm{M}$ BA. Higher concentrations (400 to $1000 \mu \mathrm{M}$ phloroglucinol) resulted in reduced growth and development of shoots and roots in vitro.

Keywords: Musa; organogenesis; plant growth regulators.

\section{INTRODUCTION}

Bananas (Musa sp.) are cultivated in over 100 countries in the tropical and subtropical regions of the world, where they constitute a major staple food crop for millions of people and fodder for animals, as well as providing a valued source of income through local and international trade [1]. Banana production has expanded in most countries for the last three decades, from 35 million tons in 1978 to 107 million tons in 2011, ranking first in fruits [2,3]. This was due to more intensive use and development of modern technology, which resulted in increased productivity.

Banana production in the United States is very limited. Florida is estimated to have about 500 acres of banana, valued at approximately $\$ 2$ million. Recently, there has been a renewed interest in expanding US banana production to satisfy various niche markets, including the market for organic and processed bananas [4].

Conventional propagation of bananas is done by suckers, which are known to perpetuate the spread of diseases and pests and the potential of variety mix-ups $[5,6]$. In contrast, in vitro propagation or micropropagation is a superior technique providing plants with vigorous growth, precocity and higher yields. Micropropagated banana plants also have high field establishment rates, uniformity in growth ensuring synchronized harvesting, and better-quality fruits $[7,8,9,10]$. Micropropagation allows the mass production of young plants, with subsequent greater distribution in shorter time, therefore attending the global demand.

The efficiency of micropropagation systems is determined by the rate of in vitro shoot production, which is directly influenced by plant growth regulators and numerous other factors [11]. Phloroglucinol (1,3,5-trihydroxybenzene) or phloroglucin (PG tautomer) is a benzenetriol that has growth regulating properties [12]. It is a phenolic compound known for its properties as a promoter of plant growth [13,14]. Studies focusing on the effects of phloroglucinol on in vitro cultures have shown to enhance growth and rate of axillary shoots in several woody plants, to initiate adventitious roots on in vitro shoots of different woody species, to enhance survival of meristems and/or shoot tips in vitro $[15,16,17]$, to enhance shoot multiplication and elongation $[18,19,20,21,22]$, and root proliferation $[23,24,25,26,27,28]$, to embryogenesis induction $[29,30]$ and to improve recovery of cryopreserved protocorms [31]. A synergistic effect with auxin during root initiation has also been reported $[17,32,13,33,14]$.

Often in vitro plants are submitted to MS medium [34] with different concentrations of BAP and/or NAA. In this work, only the floroglucinol was used to observe the development behavior of the in vitro banana plant, because in the literature was observed that we can evidence responses to the formation of shoots in several species.

Therefore, the aim of the present study was to evaluate the effects of phloroglucinol on growth and multiplication of banana cv. Grand Naine (Musa acuminata Colla group AAA) in vitro shoots, as well as root multiplication and elongation.

\section{MATERIALS AND METHODS}

\subsection{Plant Material and Experimental Location}

The experiments for this study were performed in the Ornamental Horticulture's Laboratory of the University of Florida, at the Tropical Research and Education Center, in Homestead, Florida, USA.

Three-week old banana in vitro plantlets of the cultivar Grand Naine were obtained from AgriStarts, Inc. (Apopka, FL). The in vitro plants were approximately $20 \mathrm{~cm}$ long. The aseptic in vitro plantlets were subcultured onto baby-food glass jars containing $50 \mathrm{ml}$ of MS [34] medium supplemented with $117 \mathrm{mM}$ sucrose, $\mathrm{pH}$ was adjusted to 5.7 prior to autoclaving and solidified with $0.7 \%$ agar $\left(\right.$ Fisher $^{\circledR}$, Chicago, IL, USA). The initial medium had no growth regulator. Cultures 
were maintained under controlled environmental

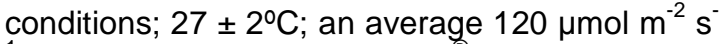
${ }^{1}$; $16 / 8$ light/dark using Philips ${ }^{\circledR}$ LED toplighting. After 20 days, shoots or plantlets (12 cm height) with four axillary buds were subdivided into $3-\mathrm{cm}$ sections and used as explants.

\subsection{Treatments}

Explants were placed on the same culture medium as described above, including a control, a treatment with 6-benzylaminopurine (6-BA) as previously reported by $[1,35]$, and five phloroglucinol treatments, as follows:

$$
\begin{aligned}
& \text { T1 }-\begin{array}{c}
\text { Control: } \mathrm{MS} \text { Basal (no plant growth } \\
\text { regulators) }
\end{array} \\
& \mathrm{T} 2-\mathrm{MS}+13.2 \mu \mathrm{M} \text { 6-BA } \\
& \mathrm{T} 3-\mathrm{MS}+200 \mu \mathrm{M} \text { of phloroglucinol } \\
& \mathrm{T} 4-\mathrm{MS}+400 \mu \mathrm{M} \text { of phloroglucinol } \\
& \mathrm{T} 5-\mathrm{MS}+600 \mu \mathrm{M} \text { of phloroglucinol } \\
& \mathrm{T} 6-\mathrm{MS}+800 \mu \mathrm{M} \text { of phloroglucinol } \\
& \mathrm{T} 7-\mathrm{MS}+1000 \mu \mathrm{M} \text { of phloroglucinol }
\end{aligned}
$$

Cultures were maintained under the same controlled environmental conditions as described above. After 4 weeks cultures were evaluated for in vitro shoot multiplication and elongation, and root induction and elongation.

\subsection{Experimental Design}

The experimental design consisted of 6 treatments plus a control, with 8 replicates of 3 shoots per treatment/control, with a total of 144 shoots used in the experiment. The entire experiment was repeated once. Shoot and root multiplication (SM, RM) were calculated by counting the number of shoots and roots per plant, respectively. Shoot and root elongation (SE, RE) were calculated by measuring the length of shoots and roots, respectively using a pachymeter. The length of shoots was measured from the leaf base of the rhizome. Survival percentage was calculated by the growth and development of normal plants that successfully survived after 30 days on in vitro conditions. The total number of inoculated explants was considered $100 \%$. Data were transformed using $\sqrt{x}+0.5$ and analyzed using analysis of variance (ANOVA). Means were compared using the Scott-Knott range test at $\alpha=0.01$.

\section{RESULTS}

After 30 days of in vitro culture, the number of banana in vitro shoots formed was higher for concentrations of $200 \mu \mathrm{M}$ phloroglucinol and 13.2 $\mu \mathrm{M} 6-\mathrm{BA}$ as compared to the control and other treatments with phloroglucinol (Table 1).

There were no significant differences for shoot multiplication between the treatments with 200 $\mu \mathrm{M}$ phloroglucinol and $13.2 \mu \mathrm{M}$ 6-BA, with production of about two shoots in each treatment.

However, significant differences were observed for shoot elongation $(2.84 \mathrm{~cm})$, number of roots (4.17) and root elongation $(4.04 \mathrm{~cm})$ under 200 $\mu \mathrm{M}$ phloroglucinol, which were significantly higher than the control and other treatments (Fig. 1).

For the number of shoots, no significant differences were observed between the control and levels of phloroglucinol varying from 400 to $1000 \mu \mathrm{M}$. For the number of roots, 400 and 600 $\mu \mathrm{M}$ phloroglucinol were similar to the control, and significantly higher than $13.2 \mu \mathrm{M} 6-\mathrm{BA}$ and 800 and $1000 \mu \mathrm{M}$ phloroglucinol. Root length showed the highest variation, with best results for $200 \mu \mathrm{M}$ phloroglucinol $(4.04 \mathrm{~cm})$ followed by the control $(3.24 \mathrm{~cm})$. There were no differences in root length between 400 and $600 \mu \mathrm{M}$ phloroglucinol (1.77 $\mathrm{cm}$ for both), and for $13.2 \mu \mathrm{M}$ 6-BA (1.17 $\mathrm{cm})$, and $800 \mu \mathrm{M}(1.14 \mathrm{~cm})$ and $1000 \mu \mathrm{M}(0.84$ $\mathrm{cm}$ ) phloroglucinol (Table 1).

For root multiplication and elongation, $200 \mu \mathrm{M}$ phloroglucinol proved to be more responsive to root induction, as higher concentrations inhibited root growth and multiplication (Table 1). This establishes a threshold concentration for organogenesis in vitro in banana plantlets cv. Grand Naine, whereby concentrations of phloroglucinol higher than $400 \mu \mathrm{M}$ can lead to a negative effect on plantlet morphogenetic responses.

Therefore, $200 \mu \mathrm{M}$ phloroglucinol appears to be the most responsive for direct organogenesis of banana's in vitro explants (Table 1).

\section{DISCUSSION}

We observed that among the phloroglucinol concentrations evaluated, the optimal concentration was $200 \mu \mathrm{M}$, whereby organogenesis responses were equal to or higher than those observed in the control.

The role of 6-BA has been recently reported for efficient in vitro shoot production in different 


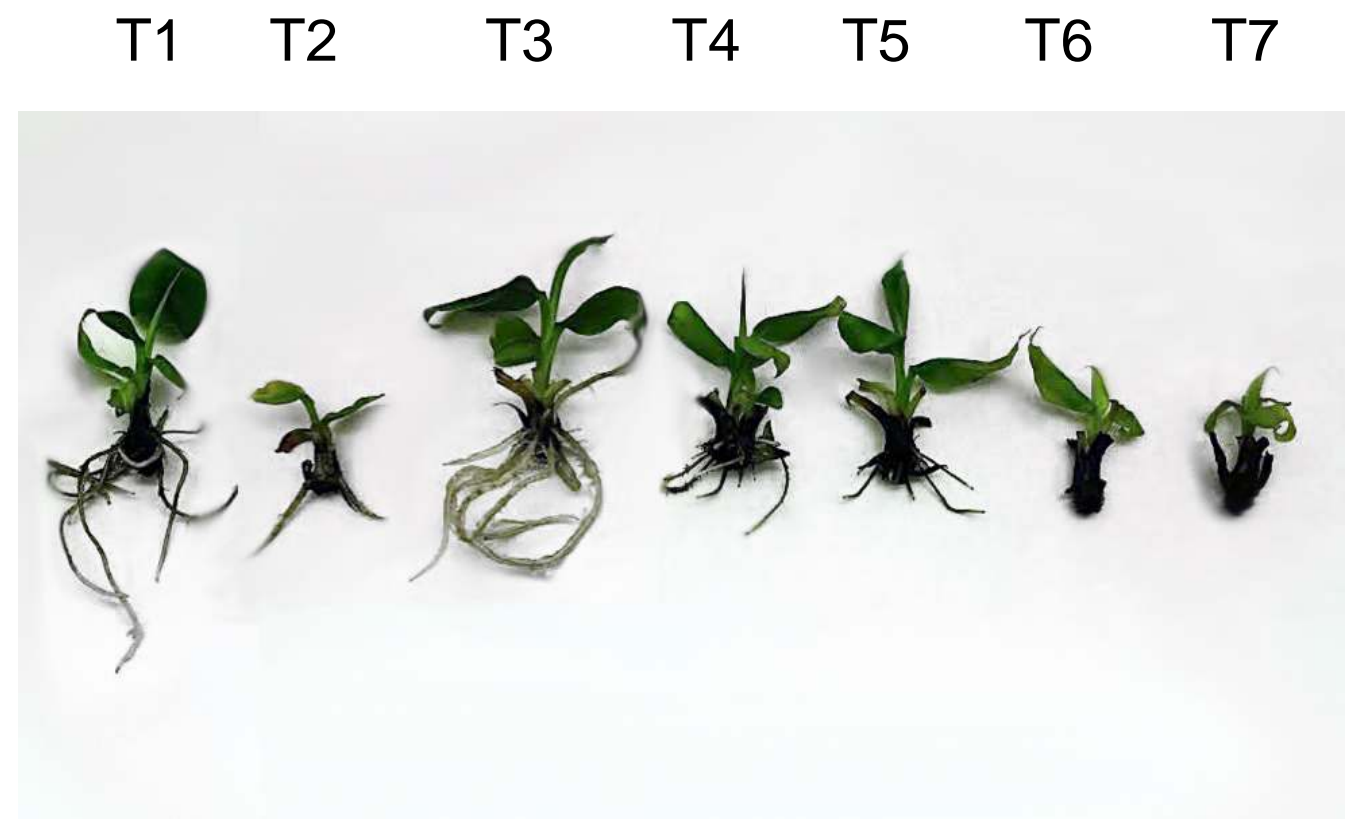

Fig. 1. Shoot and root development of in vitro banana plantlets cv. Grand Naine (bar $=1 \mathrm{~cm})$ in Murashige and Skoog (MS) basal medium (T1), MS medium with 6-benzylaminopurine (T2), and MS medium with different concentrations of phloroglucinol (T3-T7)

T1 - MS Basal; T2 - MS + $13.2 \mu M$ 6-BA; T3 - MS + $200 \mu M$ PG; T4 - MS + $400 \mu M ~ P G ; T 5-M S+600 \mu M ~ P G$; $T 6-M S+800 \mu M P G ; T 7-M S+1000 \mu M P G$

Table 1. Number of shoots, shoot elongation (length) (cm), number of roots, and root elongation (length) (cm) of in vitro banana plantlets cv. Grand Naine in Murashige and Skoog (MS) basal medium (T1), MS medium with 6-benzylaminopurine (T2), and MS medium with different concentrations of phloroglucinol (T3-T7), after 30 days cultivation

\begin{tabular}{|c|c|c|c|c|}
\hline Treatments & $\begin{array}{l}\text { Number of } \\
\text { shoots per plant }\end{array}$ & $\begin{array}{l}\text { Shoot length } \\
\text { (cm) }\end{array}$ & $\begin{array}{l}\text { Number of } \\
\text { roots per plant }\end{array}$ & $\begin{array}{l}\text { Root length } \\
\text { (cm) }\end{array}$ \\
\hline T1 - MS Basal & $1.68^{\mathrm{b}}$ & $2.32^{\mathrm{b}}$ & $3.22^{\mathrm{b}}$ & $3.24^{b}$ \\
\hline $\mathrm{T} 2-\mathrm{MS}+13.2 \mu \mathrm{M} 6-\mathrm{BA}$ & $2.01^{a}$ & $1.89^{\mathrm{d}}$ & $1.26^{c}$ & $1.17^{\mathrm{d}}$ \\
\hline $\mathrm{T} 3-\mathrm{MS}+200 \mu \mathrm{M} P G$ & $2.32^{\mathrm{a}}$ & $2.45^{\mathrm{a}}$ & $4.18^{\mathrm{a}}$ & $4.04^{\mathrm{a}}$ \\
\hline $\mathrm{T} 4-\mathrm{MS}+400 \mu \mathrm{M} P \mathrm{PG}$ & $1.60^{\mathrm{b}}$ & $2.13^{\mathrm{c}}$ & $2.44^{\mathrm{b}}$ & $1.77^{\mathrm{c}}$ \\
\hline $\mathrm{T} 5-\mathrm{MS}+600 \mu \mathrm{M} P \mathrm{G}$ & $1.87^{\mathrm{b}}$ & $2.44^{\mathrm{b}}$ & $2.67^{b}$ & $1.77^{\mathrm{c}}$ \\
\hline $\mathrm{T} 6-\mathrm{MS}+800 \mu \mathrm{M} P \mathrm{P}$ & $1.78^{\mathrm{b}}$ & $2.10^{\mathrm{c}}$ & $1.73^{\mathrm{c}}$ & $1.14^{\mathrm{a}}$ \\
\hline $\mathrm{T} 7-\mathrm{MS}+1000 \mu \mathrm{M} P \mathrm{PG}$ & $1.66^{\mathrm{b}}$ & $1.66^{\mathrm{d}}$ & $1.33^{c}$ & $0.84^{\mathrm{d}}$ \\
\hline
\end{tabular}

banana cultivars, such as Prata-Anã clone Gorutuba [1], and Amritasagar and Sabri [35]. Therefore, in our study we included a treatment with 6-BA for comparison with the different concentrations of phloroglucinol. Phloroglucinol showed superior results as compared to 6-BA, with better shoot and root elongation, and number of roots. Similarly, [13] reported that phloroglucinol has a similar effect to that of 6-BA in promoting the induction and multiplication of in vitro shoots in others species of plant.
Therefore the use of phloroglucinol in protocols for in vitro multiplication of banana cv. Grand Naine provides a positive impact for shoot multiplication and elongation, and consequently mass production of plants.

However, concentrations of phloroglucinol might need to be adjusted according to different banana cultivars, as well as for other crops or plant species. This is evidenced by several studies. [13] reported that phloroglucinol 
promoted growth and development of in vitro shoots of potato using concentrations between 80 to $1600 \mu \mathrm{M}$. [21] improved multiplication in Prunus armeniaca L. by using $800 \mu \mathrm{M}$ of phloroglucinol. [36] demonstratedthat $400 \mu \mathrm{M}$ of phloroglucinol enhanced axillary shoot proliferation in Wrightia tomentosa Roem. et Schult. Contrasting to the higher concentrations of phloroglucinol reported in the studies above, [22] observed that $39.64 \mu \mathrm{M}$ was the most responsive concentration for shoot bud elongation in Capsicum annum L.. Similarly, [37] verified that $3.9 \mu \mathrm{M}$ was sufficient to improve shoot elongation in Wrightia tomentosa. Therefore, the concentration range selected for this study was based on the existing literature.

We observed that higher concentrations of phloroglucinol $(400-1000 \mu \mathrm{M})$ showed little positive effect on in vitro multiplication of banana cv. Grand Naine. However, results similar to our study were observed with Decalepis hamiltonii, whereby $200 \mu \mathrm{M}$ of phloroglucinol promoted elongation of shoots [19].

In our study, phloroglucinol had a major role on in vitro rooting of banana cv. Grand Naine. Because it did not use auxin in the medium, phloroglucinol may have acted along with the plant's endogenous auxin and may have promoted root induction, elongation, and increasing root numbers. When comparing a study performed by [38] using $1.0 \mathrm{mg} \mathrm{L}^{-1}$ of 6 -BA with $1.0 \mathrm{mg} \mathrm{L}^{-1} \mathrm{IAA}$ for in vitro root formation in banana, 4 roots were obtained per explant. This number was similar to the number of roots obtained in our study with $200 \mu \mathrm{M}$ phloroglucinol.

Although root induction was observed in the control, composed of basal MS medium with no plant growth regulators, root number and length were inferior to those found under the concentration of $200 \mu \mathrm{M}$ phloroglucinol. The root characteristics observed for in vitro plantlets within 50 days of culture establishment under $200 \mu \mathrm{M}$ phloroglucinol were similar to the roots observed for in vitro plantlets after 150 days of culture establishment in previous studies without phloroglucinol (Londe, personal communication). Therefore, phloroglucinol appears to enhance root number and length by promoting early root induction and elongation.

In similar studies, [39] observed enhancement of rooting frequency using 79.3-198.25 $\mu \mathrm{M}$ phloroglucinol in Asparagus racemosus Willd., whereas induction and longer roots were observed [40] using $3.97 \mu \mathrm{M}$ phloroglucinol in Bacopa monnieri (L.) Wettst. [14] used the 79 $\mu \mathrm{M}$ phloroglucinol combined with $9.8 \mu \mathrm{M}$ IBA and zeolite, with a positive effect on in vitro rooting and acclimatization of shoots of papaya var. Marado/Roja. [28] recommended $80 \mu \mathrm{M}$ phloroglucinol for Citrus rootstocks, while [29] confirmed best results for Crataeva magna Hook. et Thomson using $198.25 \mu \mathrm{M}$ phloroglucinol.

The studies reported above used lower concentrations compared to our study. This suggests that rooting responses are also specific to each species. Similar to our study, [27] used $200 \mu \mathrm{M}$ phloroglucinol in Jatropha curcas L. In contrast, [25] reported that $634.4 \mu \mathrm{M}$ phloroglucinol was best for enhancing rooting in Carthamus tinctorius L. Higher concentrations of phloroglucinol were also evaluated in different studies. [41] evaluated concentrations of phloroglucinol between $1,982.5$ and 2,379 $\mu \mathrm{M}$ for Garcinia indica (Thouars) Choisy. [42] reported concentrations of $158.6-317.2 \mu \mathrm{M}$ in Prunus salicina Lindl., and [43] reported $793 \mu \mathrm{M}$ as the best concentration for Prunus domestica L.. However, specifically for banana cv. Grand Naine, we demonstrated that higher concentrations of phloroglucinol varying from $400-1,000 \mu \mathrm{M}$ would not be favorable for in vitro root induction and elongation.

Therefore, $200 \mu \mathrm{M}$ phloroglucinol proved to return better responses for in vitro root multiplication and elongation in banana cv. Grand naine. Longer roots can be induced in a short time; therefore, validating that phloroglucinol can accelerate the organogenic process in vitro. These results suggest that phloroglucinol can be used in the production of in vitro banana plants, and that it can be adapted to a large-scale in vitro mass production system, such as bioreactors.

This is the first study reporting the use of phloroglucinol for in vitro multiplication of banana. Additional studies should address the effects of phloroglucinol in plant morphogenesis, as well as for other banana cultivars. We showed that phloroglucinol successfully induced the development of shoots and roots in vitro in banana cv. Grand Naine. These results also provide valuable data that can serve as preliminary information for the continued improvement of in vitro micropropagation systems for banana. This is particularly true for the adaptation of protocols with phloroglucinol for large-scale mass production of in vitro banana 
plantlets using bioreactors, as suggested above. Additional studies with temporary immersion bioreactors are therefore warranted to improve multiplication rates.

\section{CONCLUSION}

The concentration of $200 \mu \mathrm{M}$ phloroglucinol promoted in vitro root multiplication and elongation of banana cv. Grand naine.

\section{ACKNOWLEDGEMENTS}

The authors thank the Fundação de Amparo à Pesquisa de Minas Gerais (FAPEMIG - Brazil) and the University of Florida for providing funding to support this project.

\section{COMPETING INTERESTS}

Authors have declared that no competing interests exist.

\section{REFERENCES}

1. Faria RAN, Costa AM, Londe LN, Silva JF, Ribeiro EB. Influence of the composition of encapsulation matrix of microshoots of banana (Musa sp.) cv. prata-anã gorutuba clone. Rev Bras Frutic. 2014;36:472-478.

2. FAO Food and Agriculture Organization of the United Nations; 2012.

Available:http://faostat.fao.org/site/339/def ault.aspx

(Accessed 10.13.16)

3. IBGE Instituto Brasileiro de Geografia e Estatística. Perfil da Fruticultura; 2014. Available:http://www.agricultura.mg.gov.br/ images/files/.../perfil fruticultura 2014.pdf (Accessed 09.02.2016)

4. Evans E, Ballen F. Banana market; 2012. Available:http://edis.ifas.ufl.edu

(Accessed 10.16.16)

5. Karembu M, Nguthi $F$, Ismail $H$. Biotech crops in Africa: The final frontier, ISAAA Afri Center, Nairobi, Kenya conventional sucker Var. Grand Naine Banana. Plant Archives. 2009;2:785-788.

6. Mustaffa MM, Kumar M. Banana production andtissue culture. In vitro Cell Dev-Plant. 2012;49:1-16.

7. Rao PS, Ganapathi TR, Kulkarni VM, Suprasanna P, Bapat VA Studies on microprogagation, synthetic seeds and in-vitro mutagenesis in banana. Proc Conf. on "Challenges for Banana Production and
Utilization in 21st Century" held at NRC on Banana, at Trichy during September 2425. 1996;216-227.

8. Njuguna J, Nguthi F, Karembu M, Wambugu F, Gitau D, Karuoya M. Management of Banana Disease and Pests by Use of Tissue-Cultured Planting Material in the Eastern and Central Provinces of Kenya, Poster presented at ISHS/Musa symposium held from $10^{\text {th }}$ to $14^{\text {th }}$ September 2007 at Greenway, Woods Resort South Africa; 2007.

9. Nguthi $F$, Karembu $M$, Njuguna J, Thuranira E, Muli S, Gitau D, Karuoya M. Comparison of conventional suckers with tissue-cultured planting material of Cavendish banana cultivars (Musa spp.) in central Kenya. Session: Crop management -Comparison of conventional suckers with tissue culture planting material of banana; 2009.

10. Bhanusree MR, Ravi Kumar K, Suresh CP, Shukla G, Chakravarty S. Comparative studies on tissue culture plantlet versus for Decalepis hamiltonii, an endangered shrub, under the influence of phloroglucinol. Indian J Exp Biol. 2015;42: 424-428.

11. Kulus D. Selected aspects of ornamental plants micropropagation in Poland and worldwide. Nauki Przyrodnicze. 2015; 4(10):10-25.

12. Sarkar D, Naik PS. Phloroglucinol enhances growth and rate of axillary shoot proliferation in potato shoot tip cultures in vitro. Plant Cell Tissue Org Cult. 2000;60: 139-149.

13. Teixeira da Silva JA, Dobránszki J, Ross S. Phloroglucinol in plant tissue culture. In Vitro Cell Dev Biol-Plant. 2013;49:1-16.

14. Perez LP, Montesinos YP, Olmedo JG, Rodriguez RB, Sanchez RR, Montenegro ON, Escriba RCR, Daniels D, GomezKosky R. Effect of phloroglucinol on rooting and in vitro acclimatization of papaya (Carica papaya L. var. Maradol Roja) In vitro Cell Dev Biol-Plant. 2016;52:196203.

15. Jones OP, Hatfield SGS. Root initiation in apple shoots cultured in vitro with auxins and phenolic compounds. J Hortic Sci. 1976;51:495-549.

16. James DJ, Thurbon IJ Rapid in vitro rooting of the apple root stock M.9. J Hortic Sci. 1979;54:309-311.

17. James DJ, Thurbon IJ. Shoot and root initiation in vitro in the applerootstock M.9 
and the promotive effect of phloroglucinol. J Hortic Sci. 1981;56:15-20.

18. Gururaj HB, Giridhar P, Ravishankar GA. Efficient clonal propagation method of regeneration from hypocotyl slices of mature apricot (Prunus armeniaca L.) seeds: A feasible alternative for apricot genetic engineering. Sci Hortic. 2004;128: 457-464.

19. Giridhar P, Gururaj HB, Ravishankar GA. In vitro shoot multiplication through shoot tip cultures of Decalepis hamiltonii Wight \& Arn., a threatened plant endemic to Southern India. In vitro Cell Dev Biol Plant. 2005;41:77-80.

20. Siwach P, Gill AR. Enhanced shoot multiplication in Ficus religiosa $\mathrm{L}$. in the presence of adenine sulphate, glutamine and phloroglucinol. Physiol Mol Biol Plants. 2011;17:271-280.

21. Wang $\mathrm{H}$, Alburquerque N, Burgos L, Petri C. Adventitious shoot regeneration from hypocotyl slices of mature apricot (Prunus armeniaca L.) seeds: A feasible alternative for apricot genetic engineering. Sci Hortic. 2011;128:457-464.

22. Bairwa VK, Kachhwaha S, Kothari SL. Phloroglucinol mediated shoot bud elongation in Capsicum annuum L. Nat Acad Sci Lett. 2012;35:331-335.

23. Romais E, Teixeira C, Ribeiro E, Lopes S. Efeito do floroglucinol na reaçao morfogênica in vitro de segmentos internodais de Citrus sinensis (L.) Osbeck cv. Pera. Rev Ceres. 2000;47: 113-120.

24. Buthuc-Keul AL, Deliu C. Clonal propagation of Arnica montana L., a medicinal plant. In vitro Cell Dev Biol Plant. 2001;37:581-585.

25. Sujatha $\mathrm{M}$, Kumar VD. In vitro bud regeneration of Carthamus tinctorius and wild Carthamus species from leaf explants and axillary buds. Biol Plant. 2007;51:782786.

26. Bopana N, Saxena S. In vitro regeneration of clonally uniform plants of Crataeva magna: A high value medicinal tree by axillary branching method. New Forest. 2009;38:53-65.

27. Kumar S, Kumaria S, Tandon P. Efficient in vitro plant regeneration protocol from leaf explant of Jatropha curcas $\mathrm{L}-\mathrm{a}$ promising biofuel plant. J Plant Biochemiotechnol. 2010;19:273-275.

28. Tallón $\mathrm{Cl}$, Porras I, Pérez-Tornero $\mathrm{O}$. Efficient propagation and rooting of three citrus rootstocks using different plant growth regulators. In vitro Cell Dev Biol Plant. 2012;48:488-499.

29. Find J, Grace L, Krogstrup P. Effect of antiauxins on maturation of embryogenic tissue cultures of Nordmanns fir (Abies nordmanniana). Physiol Plant. 2002;116: 231-237.

30. Reis E, Batista MT, Canhoto JM. Effect and analysis of phenolic compounds during somatic embryogenesis induction in Feijoa sellowiana Berg. Protoplasma. 2008;232:193-202.

31. Vendrame WA, Faria RT. Phloroglucinol enhances recovery and survival of cryopreserved Dendrobium nobile protocorms. Sci Hortic. 2011;128:131-135.

32. Sharifian S, Vahdati K, Mirmasoumi M, Ghaem SA. Assessment of phloroglucinol effect on rooting of tissue cultured Persian walnut. Acta Horticult. 2009;812:189-195.

33. Daud N, Faizal A, Greelen D. Adventitious rooting of Jatropha curcas $L$. is stimulated by phloroglucinol and by red LED light. In vitro Cell Dev-Plant. 2013;49:183-190.

34. Murashige T, Skoog F. A revised medium for rapid growth and bio-assays with tobacco tissue cultures. Physiol Plant. 1962;15:473-497.

35. Ferdous $\mathrm{MH}$, Masum V, Billah AA, Mehraj $\mathrm{H}$, TaufiqueT, Jamal Uddin. AFM BAP and IBA pulsing for in vitro multiplication of banana cultivars through shoot-tip culture. J Biosci Agric Res. 2015;02:87-95.

36. Purohit SD, Joshi P, Tak K, Nagori R. Development of high efficiency micropropagation protocol of an adult tree-Wrightia tomentosa. Plant Biotech Mol Markers. Springer, Berlin. 2005;2:217227.

37. Jain R, Sinha A, Kachhwaha S, Kothari SL. Micropropagation of Withania coagulans (Stocks) Dunal: A critically endangered medicinal herb. $J$ Plant Biochem Biotechnol. 2009;18:249-252.

38. Al-Amin MD, Karim MR, Amin SMR, Rahman A, Mamun ANM. In vitro micropropagation of banana (Musa spp.). Bangladesh J Agril Res. 2009;34:645-659.

39. Bopana N, Saxena S. In vitro propagation of a high value medicinal plant: Asparagus racemosus Willd. In vitro Cell Dev Biol Plant. 2008;44:525-532.

40. Ceasar SA, Maxwell SL, Prasad KB, Karthigan M, Ignacimuthu S. Highly efficient shoot regeneration of Bacopa monnieri (L.) using a two-stage culture 
procedure and assessment of genetic integrity of micropropagated plants by RAPD. Acta Physiol. 2010;32:443-452.

41. Chabukswar MM, Deodhar MA. Restoration of rooting competence in a mature plant of Garcinia indica through serial shoot tip grafting in vitro. Sci Hort. 2006;108:194-199.

42. Zou YN. Micropropagation of Chinese plum (Prunus salicina Lindl) using mature stem segments. Notulae Botanicae Horti Agrobotanici Cluj-Napoca. 2010;38:214218.

43. Petri C, Scorza R. Factors affecting adventitious regeneration from in vitro leaf explants of 'Improved French' plum, the most important dried plum cultivar in the USA. Ann Appl Bot. 2010;156:79-89.

(0) 2017 Londe et al.; This is an Open Access article distributed under the terms of the Creative Commons Attribution License (http://creativecommons.org/licenses/by/4.0), which permits unrestricted use, distribution, and reproduction in any medium, provided the original work is properly cited.

Peer-review history:

The peer review history for this paper can be accessed here: http://sciencedomain.org/review-history/19354 